\title{
Recovery of in-situ methanotrophic activity following acetylene inhibition
}

\section{Journal Article}

\section{Author(s):}

Urmann, Karin; Schroth, Martin Herbert (D; Zeyer, Josef

Publication date:

2008

Permanent link:

https://doi.org/10.3929/ethz-b-000013086

Rights / license:

In Copyright - Non-Commercial Use Permitted

Originally published in:

Biogeochemistry 89(3), https://doi.org/10.1007/s10533-008-9223-6 


\title{
Recovery of in-situ methanotrophic activity following acetylene inhibition
}

\author{
Karina Urmann · Martin H. Schroth · \\ Josef Zeyer
}

Received: 28 November 2007 / Accepted: 28 June 2008/Published online: 17 July 2008

(C) Springer Science+Business Media B.V. 2008

\begin{abstract}
Methane $\left(\mathrm{CH}_{4}\right)$ is the second most important greenhouse gas after carbon dioxide $\left(\mathrm{CO}_{2}\right)$. To understand $\mathrm{CH}_{4}$ cycling, quantitative information about microbial $\mathrm{CH}_{4}$ oxidation in soils is essential. Field methods such as the gas push-pull test (GPPT) to quantify $\mathrm{CH}_{4}$ oxidation are often used in combination with specific inhibitors, such as acetylene $\left(\mathrm{C}_{2} \mathrm{H}_{2}\right)$. Acetylene irreversibly binds to the enzyme methane monooxygenase, but little is known about recovery of $\mathrm{CH}_{4}$ oxidation activity after $\mathrm{C}_{2} \mathrm{H}_{2}$ inhibition in situ, which is important when performing several experiments at the same location. To assess recovery of $\mathrm{CH}_{4}$ oxidation activity following $\mathrm{C}_{2} \mathrm{H}_{2}$ inhibition, we performed a series of GPPTs over 8 weeks at two different locations in the vadose zone above a petroleum hydrocarbon-contaminated aquifer in Studen, Switzerland. After 4 weeks a maximum recovery of $30 \%$ and $50 \%$ of the respective initial activity was reached, with a subsequent slight drop in activity at both locations. Likely, $\mathrm{CH}_{4}$ oxidation activity and $\mathrm{CH}_{4}$ concentrations were too low to allow for rapid recovery following $\mathrm{C}_{2} \mathrm{H}_{2}$ inhibition at the studied locations. Therefore, alternative competitive inhibitors have to be evaluated for application in conjunction with GPPTs, especially for sites with low activity.
\end{abstract}

K. Urmann · M. H. Schroth $(\bowtie) \cdot$ J. Zeyer

Institute of Biogeochemistry and Pollutant Dynamics,

ETH Zurich, Universitätsstrasse 16, 8092 Zurich,

Switzerland

e-mail: martin.schroth@env.ethz.ch
Keywords Acetylene - Gas push-pull test · Inhibitor - Methanotrophs - Methane oxidation . Recovery
Abbreviations
GFC Gas flow controller
GPPT Gas push-pull test

\section{Introduction}

Microbial methane $\left(\mathrm{CH}_{4}\right)$ oxidation is a key process in the global $\mathrm{CH}_{4}$ cycle, lowering emissions of this greenhouse gas by over $50 \%$ and acting as a sink for atmospheric $\mathrm{CH}_{4}$ (Reeburgh 2003). Aerobic $\mathrm{CH}_{4}$ oxidation is mediated by methanotrophic bacteria that contain the enzyme methane monooxygenase, allowing them to use $\mathrm{CH}_{4}$ as their main source of carbon and energy (Hanson and Hanson 1996). To understand $\mathrm{CH}_{4}$ cycling and predict responses to changing climate conditions it is important to quantify $\mathrm{CH}_{4}$ oxidation. While detailed laboratory studies allow to control important parameters and to assess their influence on metabolic activity, in-situ quantification of processes provides activity estimates that are likely more representative for the studied environment (Madsen 1998; Scow and Hicks 2005).

The GPPT is a tracer test to quantify $\mathrm{CH}_{4}$ oxidation in situ, which is based on the injection of a gas mixture containing the reactants $\mathrm{CH}_{4}$ and $\mathrm{O}_{2}$ and a non- 
reactive tracer, e.g., neon $(\mathrm{Ne})$ into the vadose zone. While the injected mixture migrates away from the injection point, reactants are consumed by indigenous microorganisms. The gas mixture is subsequently pumped back, i.e., extracted together with soil air from the same location (Urmann et al. 2005). First-order rate constants of $\mathrm{CH}_{4}$ oxidation can be calculated from $\mathrm{CH}_{4}$ and tracer concentration data provided that their transport behavior is similar (Schroth and Istok 2006). To verify the latter, a GPPT with co-injection of an inhibitor for $\mathrm{CH}_{4}$ oxidation is usually performed. Alternatively, $\mathrm{CH}_{4}$ during an active test can be directly compared with $\mathrm{CH}_{4}$ during a test with an inhibitor as a substitute tracer (Urmann et al. 2007a). For an inhibitor to be effective during a GPPT, a concentration sufficient for inhibition has to be reached relatively fast within the test zone and maintained during the entire test.

Specific inhibitors are a traditional tool for the assessment of microbial processes that allows to verify microbial activity and distinguish between different processes (Oremland and Capone 1988). To quantify $\mathrm{CH}_{4}$ oxidation in situ, inhibitors have been employed in conjunction with $\mathrm{CH}_{4}$ emission measurements using chambers (e.g., Ding et al. 2004; King 1996; Kruger et al. 2001), and more recently in conjunction with tracer tests like the GPPT (Urmann et al. 2005; Urmann et al. 2007a).

Gaseous inhibitors for $\mathrm{CH}_{4}$ oxidation currently available include the traditional inhibitor acetylene $\left(\mathrm{C}_{2} \mathrm{H}_{2}\right)$ (Prior and Dalton 1985), fluoromethane $\left(\mathrm{CH}_{3} \mathrm{~F}\right)$ (Oremland and Culbertson 1992) and difluoromethane $\left(\mathrm{CH}_{2} \mathrm{~F}_{2}\right)$ (Miller et al. 1998). Acetylene effectively inhibited $\mathrm{CH}_{4}$ oxidation at concentrations as low as $10 \mu 11^{-1}$ in laboratory studies (Bodelier and Frenzel 1999; Chan and Parkin 2000) and was shown to be effective during GPPTs (Urmann et al. 2005; Urmann et al. 2007a). In contrast, higher concentrations of $100-1,000 \mu \mathrm{l}^{-1}$ for $\mathrm{CH}_{3} \mathrm{~F}$ (Chan and Parkin 2000; King 1996) and 300-500 $\mu \mathrm{l}^{-1}$ for $\mathrm{CH}_{2} \mathrm{~F}_{2}$ (Miller et al. 1998) were required for effective inhibition, and the required concentration may depend on $\mathrm{CH}_{4}$ concentrations due to the competitive nature of inhibition (Matheson et al. 1997). Furthermore, both inhibitors $\left(\mathrm{CH}_{3} \mathrm{~F}\right.$ and $\left.\mathrm{CH}_{2} \mathrm{~F}_{2}\right)$ can be consumed by methanotrophic bacteria at low concentrations (Miller et al. 1998; Oremland and Culbertson 1992). Therefore, it may be difficult to achieve effective inhibition during a GPPT using
$\mathrm{CH}_{3} \mathrm{~F}$ or $\mathrm{CH}_{2} \mathrm{~F}_{2}$. Additionally, these inhibitors are greenhouse gases (Ramaswamy et al. 2001) and expensive, while $\mathrm{C}_{2} \mathrm{H}_{2}$ is cheap, readily available, and does not act as a greenhouse gas.

However, there are two major disadvantages of $\mathrm{C}_{2} \mathrm{H}_{2}$ : First, at higher concentrations, it also inhibits methanogenesis (Chan and Parkin 2000). Therefore, the range of $\mathrm{C}_{2} \mathrm{H}_{2}$ concentrations that can be applied is limited when $\mathrm{CH}_{4}$ oxidation and methanogenesis co-occur. Fluoromethane and $\mathrm{CH}_{2} \mathrm{~F}_{2}$ also inhibit methanogenesis, but mainly acetoclastic methanogenesis and, in the case of $\mathrm{CH}_{2} \mathrm{~F}_{2}$, only at higher concentrations (Frenzel and Bosse 1996; Miller et al. 1998). Secondly, in contrast to the competitive inhibitors $\mathrm{CH}_{3} \mathrm{~F}$ and $\mathrm{CH}_{2} \mathrm{~F}_{2}, \mathrm{C}_{2} \mathrm{H}_{2}$ irreversibly binds to methane monooxygenase (Prior and Dalton 1985). Consequently, de-novo enzyme synthesis is required for activity to recover, as was shown for ammonia monooxygenase, a similar enzyme that is also inhibited by $\mathrm{C}_{2} \mathrm{H}_{2}$ (Hyman and Arp 1992). Therefore, recovery may not be immediate and knowledge about the rate of recovery is important to be able to perform several experiments at the same location in situ in conjunction with $\mathrm{C}_{2} \mathrm{H}_{2}$ inhibition. In laboratory experiments, recovery of $\mathrm{CH}_{4}$ oxidation after $\mathrm{C}_{2} \mathrm{H}_{2}$ inhibition ranged from no recovery within 14 days to recovery within one day, indicating that recovery may depend on the physiological state of the cells (Bodelier and Frenzel 1999; Miller et al. 1998). However, to our knowledge, recovery has not been assessed in detail in situ at the field scale.

Therefore, the aim of this study was to perform a series of GPPTs to evaluate recovery of in-situ methanotrophic activity following $\mathrm{C}_{2} \mathrm{H}_{2}$ inhibition. Experiments were performed in the vadose zone above a methanogenic, petroleum hydrocarbon-contaminated aquifer with relatively low $\mathrm{CH}_{4}$ oxidation activity (Urmann et al. 2005) similar to that of oxic soils, i.e., under relatively unfavorable conditions for recovery from inhibition.

\section{Materials and methods}

Field site

Recovery of microbial $\mathrm{CH}_{4}$ oxidation after $\mathrm{C}_{2} \mathrm{H}_{2}$ inhibition was assessed in the vadose zone above a petroleum hydrocarbon-contaminated, anaerobic aquifer in Studen, 


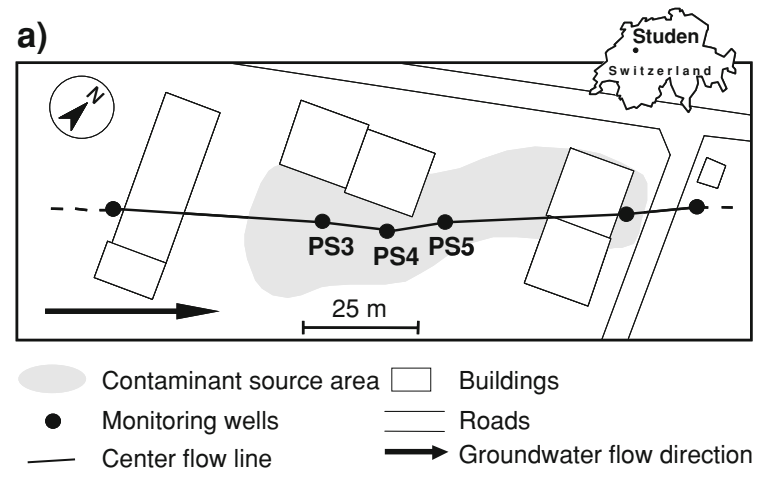

b)

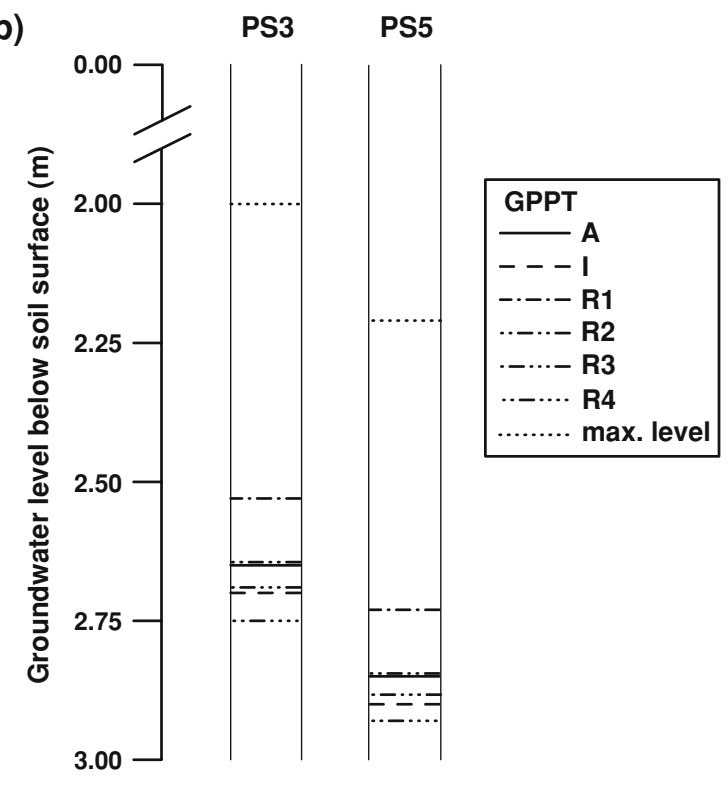

Fig. 1 Site map of the petroleum hydrocarbon-contaminated aquifer in Studen, Switzerland, showing (a) the contaminant source area and selected monitoring wells along a center flow line (adopted from Bolliger et al. 2000), and (b) groundwater levels in wells PS3 and PS5 during the time of the experiments. The maximum groundwater levels were observed between GPPT I and GPPT R1

Switzerland. Methane has been previously detected in groundwater of monitoring wells PS3, 4 and 5, all located within the contaminant source area at this site (Bolliger et al. 1999; Bolliger et al. 2000) (Fig. 1a). In earlier studies, $\mathrm{CH}_{4}$ oxidation was assessed near monitoring well PS4 using GPPTs (Urmann et al. 2005, 2008). Higher activity was observed just above the groundwater table (at $2.7 \mathrm{~m}$ depth) compared to closer to the soil surface (at $1.1 \mathrm{~m}$ depth).

In this study, GPPTs were performed at $1 \mathrm{~m}$ depth below soil surface to avoid interference of changes in the groundwater level with the test zone. Monitoring wells PS3 and PS5 were chosen as test locations as highest $\mathrm{CH}_{4}$ oxidation activity was previously observed near these wells (unpublished data), and activity had dropped near PS4 (Fig. 1a). Activity had to be high enough to be able to distinguish different levels of recovery with the currently available GPPT procedure, but was intended to be low to assess recovery under comparatively unfavorable conditions. Experiments were conducted in the annular space between each well and its surrounding 70-cmdiameter concrete casing, which was refilled with calcareous coarse sand and gravel in 1996. As a result of severe rainfall events, the groundwater level in well PS3 varied between 2.00 and $2.75 \mathrm{~m}$ and in PS5 between 2.21 and $2.90 \mathrm{~m}$ below soil surface during the time of the experiments (Fig. 1b). At $1 \mathrm{~m}$ depth, temperature remained stable around $17^{\circ} \mathrm{C}$ for the first 2 weeks of the experiments and then dropped to $12^{\circ} \mathrm{C}$ during the remaining 6 weeks.

Gas push-pull tests

A series of six GPPTs (GPPTs A, I, R1, R2, R3, R4see below) was performed at $1 \mathrm{~m}$ below soil surface near each of the two wells (Table 1). The depth refers to the depth of the tip of the injection rod permanently installed at each location. The injection gas mixtures contained on average $0.43 \mathrm{ml} \mathrm{l}^{-1}$ and 226 $\mathrm{ml}^{-1}$ of the reactants $\mathrm{CH}_{4}$ and $\mathrm{O}_{2}$, and $240 \mathrm{ml}^{-1}$ of each of the non-reactive gases $\mathrm{Ne}, \mathrm{He}$ and $\mathrm{Ar}$ (Table 1). Helium and Ar were added as additional tracers to serve as a control for Ne transport behavior. As no further information was derived from $\mathrm{He}$ and Ar breakthrough curves, data for these gases are not shown. Prior to the first GPPT (GPPT A), $\mathrm{CH}_{4}$ concentration profiles in soil air were measured following Urmann et al. (2005). Briefly, in the vicinity of each test location, a separate sampling rod was inserted to a maximum depth of $1.1 \mathrm{~m}$ below soil surface and 1-1 gas samples were extracted in 10cm vertical intervals using the GPPT equipment. An initial test, GPPT A, was subsequently performed to assess $\mathrm{CH}_{4}$ oxidation activity at each location. Within one week of GPPT A, a second test (GPPT I) was performed, additionally containing $\mathrm{C}_{2} \mathrm{H}_{2}$ as an inhibitor (Table 1). Subsequently, four tests (R1-R4) were carried out to assess recovery of $\mathrm{CH}_{4}$ oxidation activity during 8 weeks. GPPTs were performed as described earlier (Urmann et al. 2005) with slight 
Table 1 Operational parameters for gas-push pull tests (GPPTs)

\begin{tabular}{|c|c|c|c|c|c|c|c|c|}
\hline \multirow[t]{2}{*}{ Well } & \multirow[t]{2}{*}{ GPPT } & \multirow[t]{2}{*}{$\operatorname{Time}^{\mathrm{a}}(\mathrm{d})$} & \multicolumn{2}{|c|}{ Injection concentrations ${ }^{b}$} & \multicolumn{2}{|l|}{ Injection } & \multicolumn{2}{|l|}{ Extraction } \\
\hline & & & $\mathrm{CH}_{4}\left(\mathrm{ml} \mathrm{l}^{-1}\right)$ & $\mathrm{C}_{2} \mathrm{H}_{2}\left(\mathrm{ml} \mathrm{l}^{-1}\right)$ & Volume (1) & Pump rate $\left(1 \min ^{-1}\right)$ & Volume (1) & Pump rate $\left(1 \min ^{-1}\right)$ \\
\hline \multirow[t]{6}{*}{ PS3 } & A & -7 & 0.43 & - & 29.1 & 0.50 & 76.8 & 0.51 \\
\hline & I & 0 & 0.35 & 8.73 & 29.0 & 0.50 & 75.3 & 0.50 \\
\hline & R1 & 7 & 0.47 & - & 28.1 & 0.49 & 76.3 & 0.51 \\
\hline & $\mathrm{R} 2$ & 14 & 0.47 & - & 28.2 & 0.49 & 74.7 & 0.50 \\
\hline & R3 & 27 & 0.49 & - & 29.2 & 0.50 & 77.5 & 0.52 \\
\hline & $\mathrm{R} 4$ & 56 & 0.38 & - & 29.2 & 0.50 & 76.7 & 0.51 \\
\hline \multirow[t]{6}{*}{ PS5 } & A & -7 & 0.42 & - & 28.8 & 0.50 & 75.5 & 0.50 \\
\hline & I & 0 & 0.33 & 8.12 & 27.3 & 0.49 & 75.1 & 0.50 \\
\hline & R1 & 7 & 0.47 & - & 28.5 & 0.49 & 73.5 & 0.49 \\
\hline & $\mathrm{R} 2$ & 14 & 0.47 & - & 28.4 & 0.49 & 75.8 & 0.51 \\
\hline & R3 & 27 & 0.49 & - & 28.6 & 0.49 & 74.4 & 0.50 \\
\hline & $\mathrm{R} 4$ & 56 & 0.38 & - & 29.1 & 0.50 & 79.7 & 0.53 \\
\hline
\end{tabular}

${ }^{a}$ Days are given relative to the day of GPPT I

b Injection mixtures all additionally contained $210-263 \mathrm{ml} \mathrm{l}^{-1} \mathrm{He}, 221-256 \mathrm{ml} \mathrm{l}^{-1} \mathrm{Ne}, 207-243 \mathrm{ml} \mathrm{l^{-1 }} \mathrm{Ar}^{\text {and } 217-234 \mathrm{ml} \mathrm{l}} \mathrm{1}^{-1} \mathrm{O}_{2}$ and were prepared in $\mathrm{N}_{2}$

modifications. Initially, two replicate background samples of soil air were collected at $1 \mathrm{~m}$ depth through the permanently installed injection rod prior to each test. During subsequent GPPTs, between 27 and 291 of gas mixture was injected with an average flow rate of $0.491 \mathrm{~min}^{-1}$ through the injection rod (Table 1). Within $2 \mathrm{~min}$ from the end of injection, flow was reversed and between 74 and 801 were extracted from the same location with an average flow rate of $0.511 \mathrm{~min}^{-1}$. Total test duration was 3.5 h. To remove $\mathrm{C}_{2} \mathrm{H}_{2}$ after the end of GPPTs $\mathrm{I}$, extraction was continued for $2.5-3 \mathrm{~h}$ at a flow rate between 0.7 and $1.31 \mathrm{~min}^{-1}$ and occasional samples were taken to measure $\mathrm{C}_{2} \mathrm{H}_{2}$ concentrations. For injection and extraction, a gas flow controller (GFC) was used. The core equipment of the GFC was a diaphragm pump and a mass flow meter (Urmann et al. 2005). Note that units of 1 and $\mathrm{ml}$ of gas in this paper all refer to volumes normalized to $0 \mathrm{C}$. Deviating from previous procedures, injection and extraction samples were collected with +0.6 bar pressure in gas-tight 20-ml GC-autosampler vials with butyl rubber stoppers. Samples were analyzed for $\mathrm{CH}_{4}$ and $\mathrm{C}_{2} \mathrm{H}_{2}$ by gas chromatography with a FID detector and a Hayesep-N column at $85 \mathrm{C}$ (Urmann et al. 2005). Acetylene was quantified down to a concentration of $0.01 \mu \mathrm{l} \mathrm{l}^{-1}$, the detection limit was around a factor of 10 lower. Furthermore, samples for noble gases and $\mathrm{O}_{2}$ were analyzed by gas chromatography with a TCD detector and a molecular-sieve column (10-m long, 2-mm i.d., packed with Molsieve $5 \mathrm{~A})$ at $35 \mathrm{C}$ with a back-flushed pre-column to remove $\mathrm{CO}_{2}$ and $\mathrm{H}_{2} \mathrm{O}$ (Gonzalez-Gil et al. 2007). As $\mathrm{O}_{2}$ concentrations were two orders of magnitude higher than $\mathrm{CH}_{4}$ concentrations during all tests, $\mathrm{O}_{2}$ was considered non-limiting. Therefore, $\mathrm{O}_{2}$ data were not further analyzed and are not shown.

\section{Estimation of kinetic parameters}

To obtain breakthrough curves of the different gases, relative concentrations $\left(C^{*}\right)$ were calculated by dividing concentrations in extraction samples by the concentration in the respective injection gas mixture (Table 1) and plotted versus time since end of injection. Prior to these calculations, concentrations in GPPT extraction samples were corrected for their background concentrations measured in soil air $\left(\mathrm{CH}_{4}\right.$ 0.27-1.12 $\mu \mathrm{l} \mathrm{l}^{-1}$, Ne below detection) (Urmann et al. 2005). From this point forward corrected values will be referred to as $\mathrm{CH}_{4}$. A simplified method was used to evaluate GPPTs, which accounts for reaction (in this case $\mathrm{CH}_{4}$ oxidation) during both injection and extraction phases of a GPPT even when only a segment of the GPPT extraction breakthrough curve is evaluated (Schroth and Istok 2006). In this method, the gas 
mixture is imagined to consist of individual "parcels" that are sequentially injected into the soil. It is further assumed that no mixing occurs between individual parcels during gas transport in soil. To apply this method, a residence time $t_{\mathrm{R}}$ was calculated for each parcel (i.e., sample) $j$ collected during extraction, which is the time from its injection until its extraction (Eq. 1):

$t_{\mathrm{R}}^{j}=t^{* j}+\frac{\int_{t_{\mathrm{ext}=0}}^{t_{\mathrm{ext}}^{j}} Q_{\mathrm{ext}} C_{\mathrm{Ne}}(t) d t}{M_{\mathrm{Ne}}} T_{\mathrm{inj}}$

where $t^{*}$ is time since end of injection, $Q_{\text {ext }}$ is the extraction pump rate, $t_{\mathrm{ext}}$ is time since extraction began, $M_{\mathrm{Ne}}$ is the total mass of the tracer Ne injected, $C_{\mathrm{Ne}}$ is the Ne concentration at time $t_{\mathrm{ext}}$ and $T_{\mathrm{inj}}$ is the injection time. Subsequently, the natural logarithm of the ratio of relative concentration $C^{*}$ of $\mathrm{CH}_{4}$ and $\mathrm{Ne}$ was plotted versus residence time $t_{\mathrm{R}}$ (Eq. 2). Neon thereby accounts for dilution of the injected gas mixture with soil air.

$\ln \left(\frac{C_{\mathrm{CH}_{4}}^{*}\left(t^{*}\right)}{C_{\mathrm{Ne}}^{*}\left(t^{*}\right)}\right)=-k_{\mathrm{app}} t_{\mathrm{R}}+c$

Apparent first-order rate constants $k_{\text {app }}$ and corresponding $95 \%$ confidence intervals were calculated by linear regression from the segment of the data that showed a ln-linear relationship according to Eq. 2 with $c$ as an arbitrary constant. In those cases where the entire dataset was linear, $c$ was set to 0 (Schroth and Istok 2006).

\section{Results}

Methane gas concentrations in depth profiles at both locations were similar to or below atmospheric $\mathrm{CH}_{4}$ concentrations. Concentrations decreased with depth indicating uptake of atmospheric $\mathrm{CH}_{4}$ into the soil (data not shown).

Relative $\mathrm{CH}_{4}$ concentrations near both wells during the initial GPPT A were considerably lower than relative concentrations of the tracer $\mathrm{Ne}$ (Fig. 2), indicating $\mathrm{CH}_{4}$ oxidation occurring at both locations. The almost linear relationship between $\ln \left(C_{\mathrm{CH}_{4}}^{*} / C_{\mathrm{Ne}}^{*}\right)$ and $t_{\mathrm{R}}$ showed that $\mathrm{CH}_{4}$ oxidation approximately followed apparent first-order kinetics throughout the entire GPPT A at both locations (Fig. 3). At PS5, the apparent first-order rate constant $k_{\text {app }}$ for $\mathrm{CH}_{4}$ oxidation determined from GPPT A was $0.67 \mathrm{~h}^{-1}$ compared to $1.16 \mathrm{~h}^{-1}$ at PS3 (Fig. 4).

In contrast to GPPT A, breakthrough curves of $\mathrm{CH}_{4}$ and $\mathrm{Ne}$, as well as $\mathrm{C}_{2} \mathrm{H}_{2}$, nearly coincided during both GPPT I, the tests with the co-injection of $\mathrm{C}_{2} \mathrm{H}_{2}$ as an inhibitor (Fig. 2). This confirmed similar transport behavior of reactant and tracer under the test conditions applied during all GPPTs, which is a pre-requisite for rate calculations (Urmann et al. 2005). Only in the first third of extraction of GPPT I at PS5, a slightly higher $\mathrm{CH}_{4}$ breakthrough curve compared to the Ne breakthrough curve was observed (Fig. 2). These slight deviations indicated a larger influence of diffusion at the beginning of extraction at PS5. Under diffusiondominated transport conditions, relative $\mathrm{CH}_{4}$ concentrations in breakthrough curves were previously found to be higher than relative Ne concentrations (GonzalezGil et al. 2007; Urmann et al. 2007a). As Ne cannot be used as a tracer for $\mathrm{CH}_{4}$ under these conditions, only breakthrough curves from the later part of extraction $\left(t_{\mathrm{R}}\right.$ $>1.35 \mathrm{~h}$ ) were used for data analysis of all GPPTs (A, I and R1-4) at PS5 (Fig. 3). Small apparent first-order rate constants, computed from GPPT I at both locations (Fig. 4) were in accordance with similar breakthrough curves of $\mathrm{Ne}$ and $\mathrm{CH}_{4}$ and inhibition of $\mathrm{CH}_{4}$ oxidation activity (Fig. 2).

At the end of extraction of both GPPT I, $\mathrm{C}_{2} \mathrm{H}_{2}$ concentrations of 0.52 and $0.60 \mathrm{ml} \mathrm{l}^{-1}$ were observed at PS3 and PS5, respectively. Remaining $\mathrm{C}_{2} \mathrm{H}_{2}$ was extracted at a higher pump rate for $2.5-3 \mathrm{~h}$, which decreased $\mathrm{C}_{2} \mathrm{H}_{2}$ concentrations by a factor of 10 . During additional GPPTs two days after inhibition (data not shown), maximum $\mathrm{C}_{2} \mathrm{H}_{2}$ concentrations of 0.4 and $4.4 \mu \mathrm{l} \mathrm{l}^{-1}$ were detected at PS3 and PS5, respectively. After 1 week, during GPPT R1, no $\mathrm{C}_{2} \mathrm{H}_{2}$ was detected at PS3 while up to $0.03 \mu 11^{-1}$ was detected at PS5, which was gone one week later, during GPPT R2.

In the 8 weeks following inhibition, $\mathrm{CH}_{4}$ oxidation activity partially recovered, as indicated by lower relative $\mathrm{CH}_{4}$ concentrations compared to relative $\mathrm{Ne}$ concentrations (see data from GPPT R4 in Fig. 2). Accordingly, the slopes of rate plots increased again in comparison to GPPT I (Fig. 3). In contrast to GPPT $\mathrm{A}, \mathrm{CH}_{4}$ oxidation followed apparent Michaelis-Menten kinetics in the first part and apparent firstorder kinetics only in the later part of extraction in all GPPT $\mathrm{R}$ as indicated by curved rate plots at the beginning of extraction (Fig. 3). Apparent first-order 
Fig. 2 Neon and $\mathrm{CH}_{4}$ breakthrough curves at PS3 and PS5 during gas pushpull tests (GPPTs) before inhibition (GPPT A), during the GPPT with the inhibitor $\mathrm{C}_{2} \mathrm{H}_{2}$ (GPPT I) and 8 weeks after inhibition (GPPT R4). For GPPT I, $\mathrm{C}_{2} \mathrm{H}_{2}$ breakthrough curves are shown in addition
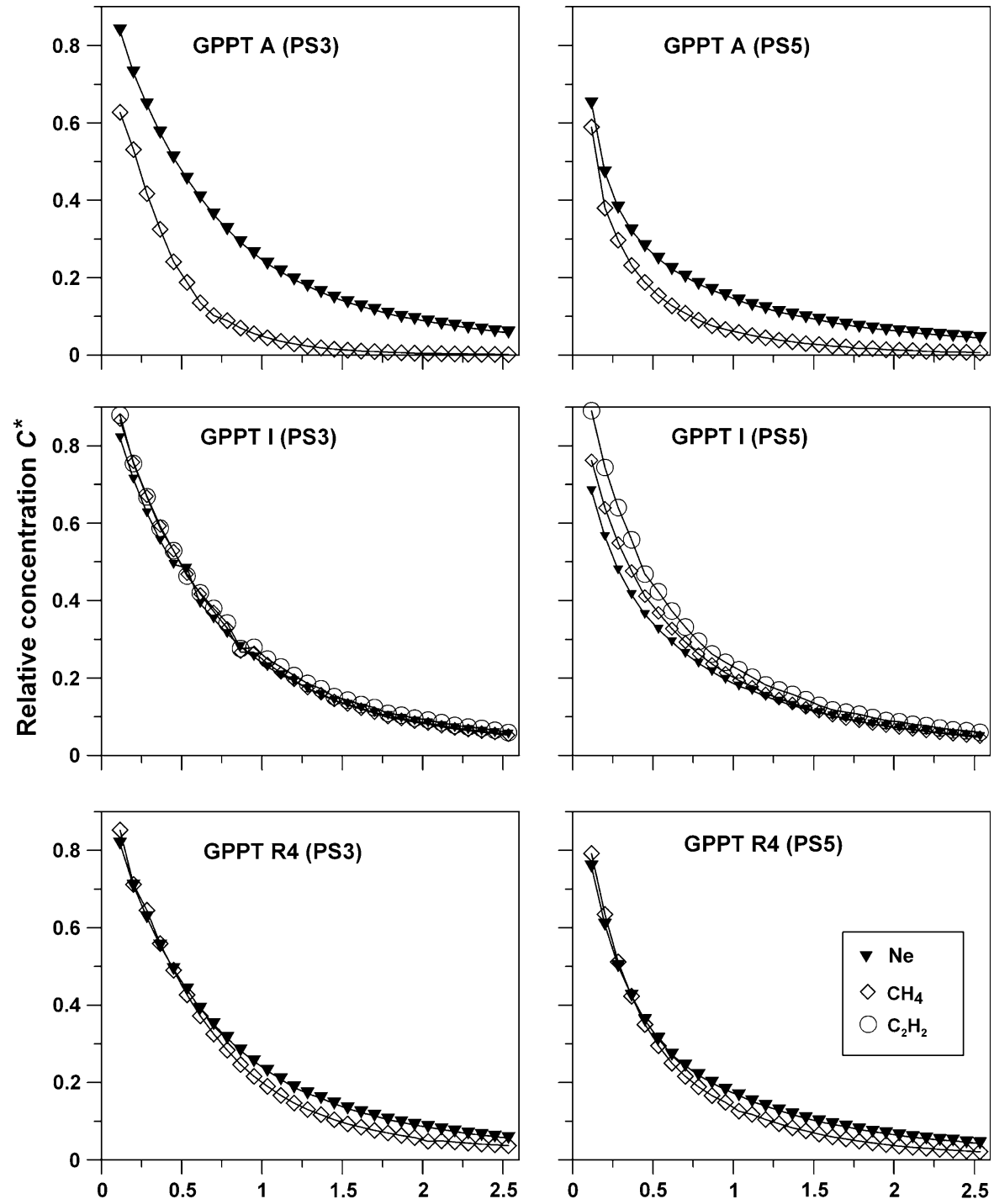

Time since end of injection $t^{\star}$ [h]

rate constants, computed from linear parts of rate plots, increased during the first week leading to a recovery of $28 \%$ of the initial activity at both PS3 and PS5 (Fig. 4). At PS5, activity continued to recover at a lower rate during the following three weeks with recovery reaching 50\% 4 weeks after inhibition. However, after 8 weeks, activity dropped to $43 \%$ of initial activity. In contrast, at PS3, activity did not recover any further between 1 and 4 weeks after inhibition and then dropped to $22 \%$ of initial activity 8 weeks after inhibition. Despite the different rates and percentages of recovery, apparent first-order rate constants were very similar at both locations four and eight weeks after inhibition (Fig. 4).

\section{Discussion}

We studied recovery of $\mathrm{CH}_{4}$ oxidation activity at two locations above a petroleum-hydrocarbon contaminated aquifer after inhibition with $\mathrm{C}_{2} \mathrm{H}_{2}$. In accordance with previous experiments (Urmann et al. 2005), effective inhibition was confirmed in GPPTs at both test locations by similar $\mathrm{Ne}$ and $\mathrm{CH}_{4}$ breakthrough curves resulting in small apparent first-order rate constants (Fig. 4) and by sufficient inhibitor concentrations throughout the entire tests. Similar $\mathrm{C}_{2} \mathrm{H}_{2}$ and $\mathrm{CH}_{4}$ breakthrough curves furthermore confirmed that the inhibitor was distributed in the test zone similar to the reactant (Fig. 2, Schroth et al. 2001). In previous experiments, effective $\mathrm{C}_{2} \mathrm{H}_{2}$ 


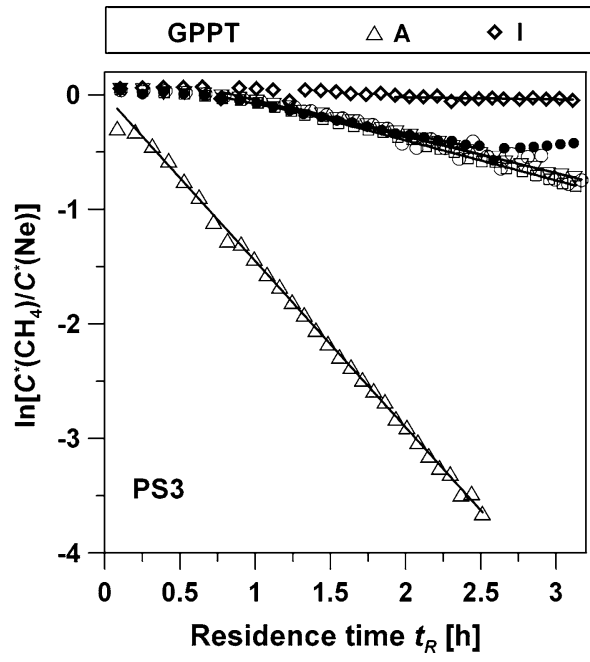

Fig. 3 Plots for rate calculations from gas push-pull tests (GPPTs) at PS3 and PS5. Apparent first-order rate constants were derived from the slopes by linear regression (solid lines).

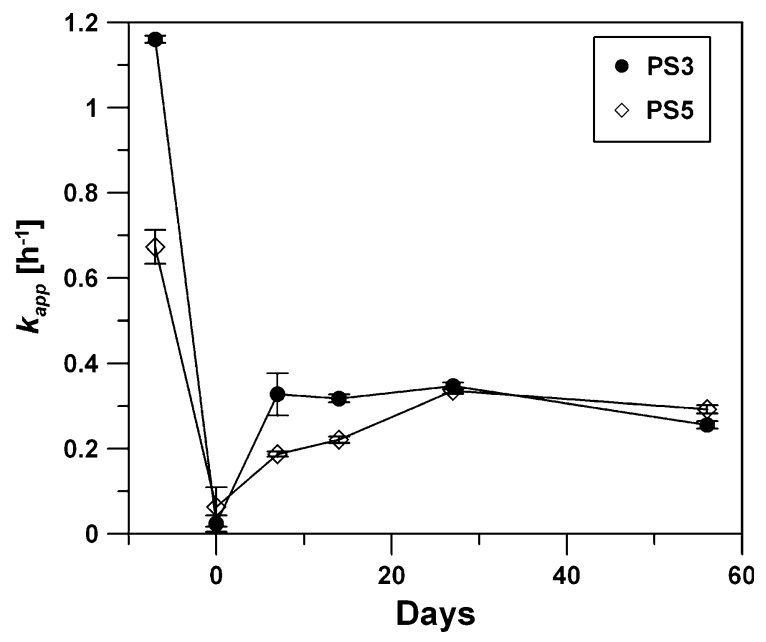

Fig. 4 Apparent first-order rate constants $k_{\text {app }}$ for $\mathrm{CH}_{4}$ oxidation at PS3 and PS5 before, during, and up to 8 weeks after inhibition with $\mathrm{C}_{2} \mathrm{H}_{2}$. Day 0 is the day of inhibition. Error bars represent $95 \%$ confidence intervals

inhibition during a comparable GPPT was additionally confirmed by $\mathrm{CH}_{4}$ stable carbon isotope data (Urmann et al. 2005). However, when applying this method in future studies, it should be noted that the amount of $\mathrm{C}_{2} \mathrm{H}_{2}$ necessary for effective inhibition may vary between different environments.

In this study, we report apparent first-order rate constants $k_{\text {app }}$ as a measure of activity. According to Michaelis-Menten kinetics, $k$ is defined as the ratio of maximum activity $V_{\max }$ over the affinity constant $K_{\mathrm{m}}$

$\circ \mathbf{R} 1 \quad \nabla \mathbf{R 2} \quad \square \mathbf{R} 3 \quad \bullet \mathbf{R} 4$

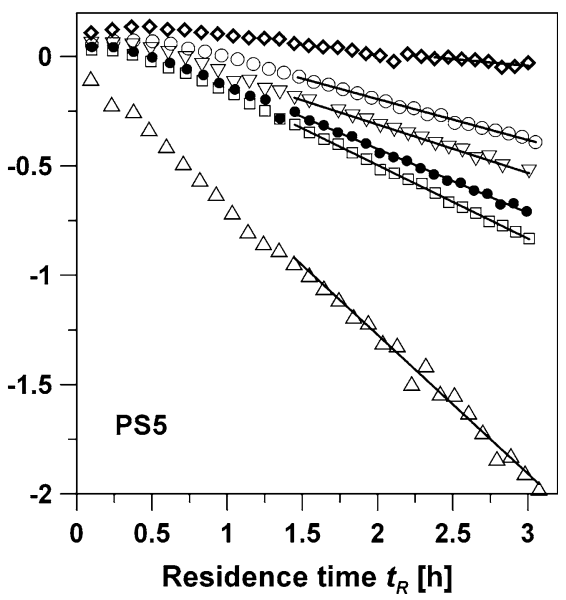

At PS5, data were only evaluated for $t_{\mathrm{R}}>1.35 \mathrm{~h}$ due to deviating transport behavior of $\mathrm{CH}_{4}$ and $\mathrm{Ne}$ at the beginning of extraction

for substrate concentrations much smaller than $K_{\mathrm{m}}$. Assuming that $K_{\mathrm{m}}$ remained constant during our experiments, a higher $k$ means a higher $V_{\max }$, which in turn implies the presence of more enzyme for $\mathrm{CH}_{4}$ oxidation (Dunn et al. 1992). Considering GPPT results, apparent first-order rate constants contain more information about the intrinsic activity of the cells or enzymes than $\mathrm{CH}_{4}$ turnover rates, calculated by multiplying $k_{\text {app }}$ with $\mathrm{CH}_{4}$ concentrations, as the latter would be influenced by variations in $\mathrm{CH}_{4}$ test concentrations. However, to directly compare apparent firstorder rate constants, $k_{\text {app }}$-values should be obtained under the same conditions, as values may depend on the physical conditions under which they were determined (Urmann et al. 2007b). As all tests were performed under nearly the same test conditions at the same site, this is valid for the presented experiments.

Comparing the $k_{\text {app }}$-values with previous GPPTs at the same site, the apparent first-order rate constant for $\mathrm{CH}_{4}$ oxidation at PS5 during GPPT A was similar to rate constants previously determined at a similar depth at PS4 (Urmann et al. 2005, 2008) (Fig. 1a). During a GPPT 3 months prior to GPPT A, a similar $k_{\text {app }}$ of $0.63 \mathrm{~h}^{-1}$ was also determined at PS3. This may indicate that the higher observed rate constant at PS3 during GPPT A $\left(1.16 \mathrm{~h}^{-1}\right)$, i.e., the higher activity, was induced by high $\mathrm{CH}_{4}$ concentrations of up to $3 \mathrm{ml} \mathrm{l}^{-1}$ observed in the test zone during a significant rise in the water table 12 days prior to GPPT A. A second rise in the water table occurred 2 
days after inhibition (max. groundwater level in Fig. 1b) leading to a high $\mathrm{CH}_{4}$ background concentration of $0.68 \mathrm{ml}^{-1}$ at PS3 and a slightly enhanced $\mathrm{CH}_{4}$ background concentration at PS5. This impeded quantitative analysis of additional GPPTs performed on this day (data not shown).

The high water solubility of $\mathrm{C}_{2} \mathrm{H}_{2}$ (Wilhelm et al. 1977) and its strong adsorption to surfaces made it difficult to totally remove $\mathrm{C}_{2} \mathrm{H}_{2}$ from the soil. However, despite small concentrations still being observed after 2 days and at PS5 even after 1 week, recovery was fastest during the first week after inhibition at both locations. At PS3 maximum recovery was already reached after 1 week, while at PS5 recovery continued until 4 weeks after inhibition. As de-novo enzyme synthesis is assumed to be required for recovery from $\mathrm{C}_{2} \mathrm{H}_{2}$ inhibition (Hyman and Arp 1992), it was proposed that the physiological status of methanotrophic cells at the time of $\mathrm{C}_{2} \mathrm{H}_{2}$ addition determines their ability to recover (Bodelier and Frenzel 1999). For example, in laboratory incubations of rice field soils, $\mathrm{CH}_{4}$ oxidation activity recovered from 24-h-long exposure to $10-10,000 \mu \mathrm{l}$ $1^{-1} \mathrm{C}_{2} \mathrm{H}_{2}$ within one day when cells were activated by incubation with $1,000 \mu \mathrm{l}^{-1} \mathrm{CH}_{4}$ for $24 \mathrm{~h}$ prior to inhibition. In contrast, without pre-incubation with $\mathrm{CH}_{4}$, activity did not recover at all from the same exposure to $\mathrm{C}_{2} \mathrm{H}_{2}$ within $90 \mathrm{~h}$ (Bodelier and Frenzel 1999). Similarly, $\mathrm{CH}_{4}$ oxidation did not recover within 14 day after exposure to $10 \mathrm{ml} \mathrm{l}^{-1} \mathrm{C}_{2} \mathrm{H}_{2}$ for 24 $\mathrm{h}$ in soil that was not pre-incubated with $\mathrm{CH}_{4}$ (Miller et al. 1998). In a field study, $\mathrm{CH}_{4}$ oxidation was quantified in a freshwater marsh by comparing $\mathrm{CH}_{4}$ emissions of a $50 \mathrm{~cm} \times 50 \mathrm{~cm}$ plot covered by a chamber after $20 \mathrm{~h}$ of incubation with $40 \mathrm{ml} \mathrm{l}^{-1} \mathrm{C}_{2} \mathrm{H}_{2}$ with $\mathrm{CH}_{4}$ emissions without $\mathrm{C}_{2} \mathrm{H}_{2}$ addition. Comparison of a time series of these experiments with an alternative method suggested that $\mathrm{CH}_{4}$ oxidation fully recovered in less than a month at this field site (Ding et al. 2004). In contrast to the freshwater marsh, insitu $\mathrm{CH}_{4}$ concentrations at our site were several orders of magnitude lower. Nonetheless, methanotrophic bacteria were active before addition of $\mathrm{C}_{2} \mathrm{H}_{2}$ in our experiments, which may explain the observed partial recovery from $\mathrm{C}_{2} \mathrm{H}_{2}$ inhibition. However, the low level of activity, due to exposure to near atmospheric $\mathrm{CH}_{4}$ concentrations at most times, together with continued low availability of $\mathrm{CH}_{4}$ after inhibition likely slowed down recovery and prevented cells from reaching their initial activity within the 8 weeks of our experiments. Exposure to higher $\mathrm{CH}_{4}$ concentrations at PS3 before and/or after inhibition might explain why at PS3 the maximum rate constant after inhibition was reached faster. The slight drop in activity between 4 and 8 weeks after inhibition may have been a seasonal effect or natural fluctuations overlaying the recovery process. Temperature dropped by $5 \mathrm{C}$ during the duration of the experiments and even though temperature effects on $\mathrm{CH}_{4}$ oxidation under substrate-limited conditions were usually found to be small (Mosier et al. 1996; Whalen and Reeburgh 1996), temperature could have played a role in the slight decrease in activity. Similarly, although not measured, soil moisture might have played a role as it likely varied during the time of the experiments as a result of the severe rainfall events.

\section{Conclusions and implications}

Using a series of GPPT field experiments, we showed that recovery of $\mathrm{CH}_{4}$ oxidation activity following $\mathrm{C}_{2} \mathrm{H}_{2}$ inhibition was slow and activity only recovered by up to $50 \%$. At the studied locations, caution should therefore be exercised when performing a series of experiments to assess $\mathrm{CH}_{4}$ oxidation with a method comprising $\mathrm{C}_{2} \mathrm{H}_{2}$ inhibition, as the recovery process may mask natural trends. However, recovery time will likely vary between different environments and the studied locations may represent relatively unfavorable conditions for recovery as in situ $\mathrm{CH}_{4}$ concentrations and activities were low. Recovery may be significantly faster at sites with high $\mathrm{CH}_{4}$ concentrations and high $\mathrm{CH}_{4}$ oxidation activity as observed in a laboratory study (Bodelier and Frenzel 1999) and indicated by results from a field study (Ding et al. 2004). However, this requires further investigation. To overcome the problem of slow recovery from $\mathrm{C}_{2} \mathrm{H}_{2}$ inhibition, alternative inhibitors will be evaluated in conjunction with GPPTs, especially for sites with low $\mathrm{CH}_{4}$ oxidation activity.

Acknowledgements We would like to thank Guy Kneip for his initial work on recovery from $\mathrm{C}_{2} \mathrm{H}_{2}$ inhibition, which provided valuable information for this study. We would also like to thank Rang Cho, David Müller, Philipp Nauer and Juliane Wischnewski (ETH Zurich) for help with field work. Funding for the research was provided by ETH Zurich, in part through Grant TH-20 06-3. Helpful suggestions by two anonymous reviewers were greatly appreciated. 


\section{References}

Bodelier PLE, Frenzel P (1999) Contribution of methanotrophic and nitrifying bacteria to $\mathrm{CH}_{4}$ and $\mathrm{NH}_{4}{ }^{+}$oxidation in the rhizosphere of rice plants as determined by new methods of discrimination. Appl Environ Microbiol 65:1826-1833

Bolliger C, Höhener P, Hunkeler D, Häberli K, Zeyer J (1999) Intrinsic bioremediation of a petroleum hydrocarboncontaminated aquifer and assessment of mineralization based on stable carbon isotopes. Biodegradation 10:201217. doi:10.1023/A:1008375213687

Bolliger C, Schönholzer F, Schroth MH, Hahn D, Bernasconi S, Zeyer J (2000) Characterizing intrinsic bioremediation in a petroleum hydrocarbon-contaminated aquifer by combined chemical, isotopic and biological analyses. Biorem J 4:359-371. doi:10.1080/10889860091114301

Chan ASK, Parkin TB (2000) Evaluation of potential inhibitors of methanogenesis and methane oxidation in a landfill cover soil. Soil Biol Biochem 32:1581-1590. doi: 10.1016/S0038-0717(00)00071-7

Ding W, Cai Z, Tsuruta H (2004) Summertime variation of methane oxidation in the rhizosphere of a Carex dominated freshwater marsh. Atmos Environ 38:4165-4173. doi:10.1016/j.atmosenv.2004.04.022

Dunn IJ, Heinzele E, Ingham J, Preenosil IE (1992) Biological reaction engineering - principles, applications and modelling with PC simulations. VCH, D-Weinheim

Frenzel P, Bosse U (1996) Methyl fluoride, an inhibitor of methane oxidation and methane production. FEMS Microbiol Ecol 21:25-36. doi:10.1111/j.1574-6941.1996. tb00330.x

Gonzalez-Gil G, Schroth MH, Zeyer J (2007) Transport of methane and noble gases during gas push-pull tests in dry porous media. Environ Sci Technol 41:3262-3268. doi: 10.1021/es0618752

Hanson RS, Hanson TE (1996) Methanotrophic bacteria. Microbiol Rev 60:439-471

Hyman MR, Arp DJ (1992) ${ }^{14} \mathrm{C}_{2} \mathrm{H}_{2}$ - and ${ }^{14} \mathrm{CO}_{2}$-labeling studies of the de Novo synthesis of polypeptides by Nitrosomonas europaea during recovery from acetylene and light inactivation of ammonia monooxygenase. J Biol Chem 267:1534-1545

King GM (1996) In situ analyses of methane oxidation associated with the roots and rhizomes of a bur reed, Sparganium eurycarpum, in a Maine wetland. Appl Environ Microbiol 62:4548-4555

Kruger M, Frenzel P, Conrad R (2001) Microbial processes influencing methane emission from rice fields. Glob Change Biol 7:49-63. doi:10.1046/j.1365-2486.2001.00395.x

Madsen EL (1998) Epistemology of environmental microbiology. Environ Sci Technol 32:429-439. doi:10.1021/ es970551y

Matheson LJ, Jahnke LL, Oremland RS (1997) Inhibition of methane oxidation by Methylococcus capsulatus with hydrochlorofluorocarbons and fluorinated methanes. Appl Environ Microbiol 63:2952-2956

Miller LG, Sasson C, Oremland RS (1998) Difluoromethane, a new and improved inhibitor of methanotrophy. Appl Environ Microbiol 64:4357-4362
Mosier AR, Parton WJ, Valentine DW, Ojima DS, Schimel DS, Delgado JA (1996) $\mathrm{CH}_{4}$ and $\mathrm{N}_{2} \mathrm{O}$ fluxes in the Colorado shortgrass steppe: 1. Impact of landscape and nitrogen addition. Global Biogeochem Cycles 10:387-399. doi: 10.1029/96GB01454

Oremland RS, Capone DG (1988) Use of specific inhibitors in biogeochemistry and microbial ecology. Adv Microb Ecol 10:285-383

Oremland RS, Culbertson CW (1992) Importance of methaneoxidizing bacteria in the methane budget as revealed by the use of a specific inhibitor. Nature 356:421-423. doi: $10.1038 / 356421 \mathrm{a} 0$

Prior SD, Dalton H (1985) Acetylene as a suicide substrate and active site probe for methane monooxygenase from Methylococcus capsulatus (Bath). FEMS Microbiol Lett 29:105-109. doi:10.1111/j.1574-6968.1985.tb00843.x

Ramaswamy V, Boucher O, Haigh J, Hauglustaine J, Haywood J, Myhre G et al (2001) Radiative forcing of climate change. In: Houghton JT, Ding Y, Griggs DJ, Noguer M, van der Linden PJ, Dai X, Maskell K, Johnson CA (eds) IPCC third assessment report - climate change 2001: the scientific basis. Cambridge University Press, Cambridge, pp 349-416

Reeburgh WS (2003) Global methane biogeochemistry. In: Holland HD, Turekian KK (eds) Treatise on geochemistry. Elsevier, New York, pp 65-89

Schroth MH, Istok JD (2006) Models to determine first-order rate coefficients from single-well push-pull tests. Ground Water 44:275-283

Schroth MH, Istok JD, Haggerty R (2001) In situ evaluation of solute retardation using single-well push-pull tests. Adv Water Resour 24:105-117. doi:10.1016/S0309-1708(00) 00023-3

Scow KM, Hicks KA (2005) Natural attenuation and enhanced bioremediation of organic contaminants in groundwater. Curr Opin Biotechnol 16:246-253. doi:10.1016/j.copbio. 2005.03.009

Urmann K, Gonzalez-Gil G, Schroth MH, Hofer M, Zeyer J (2005) New field method: gas push-pull test for the in-situ quantification of microbial activities in the vadose zone. Environ Sci Technol 39:304-310. doi:10.1021/es0495720

Urmann K, Gonzalez-Gil G, Schroth MH, Zeyer J (2007a) Quantification of microbial methane oxidation in an alpine peat bog. Vadose Zone J 6:705-712. doi:10.2136/ vzj2006.0185

Urmann K, Norina SE, Schroth MH, Zeyer J (2007b) Methanotrophic activity in a diffusive methane/oxygen counter-gradient in an unsaturated porous medium. J Contam Hydrol 94:126-138. doi:10.1016/j.jconhyd.2007. 05.006

Urmann K, Schroth MH, Noll M, Gonzalez-Gil G, Zeyer J (2008) Assessment of microbial methane oxidation above a petroleum-contaminated aquifer using a combination of in-situ techniques. J Geophys Res Biogeosci 113. doi: 10.1029/2006JG000363

Whalen SC, Reeburgh WS (1996) Moisture and temperature sensitivity of $\mathrm{CH}_{4}$ oxidation in boreal soils. Soil Biol Biochem 28:1271-1281. doi:10.1016/S0038-0717(96)00139-3

Wilhelm E, Battino R, Wilcock RJ (1977) Low-pressure solubility of gases in liquid water. Chem Rev 77:219-262. doi:10.1021/cr60306a003 